\title{
EFL Teachers' Self-regulation and Job Performance
}

\author{
Atiyeh Kamyabi Gol \\ Department of Linguistics, Faculty of Letters and Humanities, Ferdowsi University of Mashhad, Mashhad, Iran \\ Nahid Royaei \\ Imam Reza International University, Iran
}

\begin{abstract}
The current study explored the relationship between Iranian EFL teachers' self-regulation and job performance. To empirically explore the postulated correlation between teachers' self-regulation and job performance, 80 EFL teachers from various language institutes in Mashhad were asked to complete the "Teachers Self-Regulation Scale" and the "Job Performance Scale". The results of the finding confirmed the hypothesized relationship between teachers' self-regulation and job performance. Moreover, the result of StepWise Regression Analysis revealed that mastery goal orientation among sub-components of self-regulation was the best predicator of job performance. Finally, the results were discussed in details and implications were recommended.
\end{abstract}

Index Terms—self-regulation, job performance, EFL teachers, correlation

\section{INTRODUCTION}

According to Motowildlo (2003, p.42) "job performance is defined as the total expected value to the organization of the discrete behavioral episodes that an individual carries out over a standard period of time". A definition of job performance is beneficial for the domain of techniques that the industrial and organizational (I /O) psychology may employ to enhance individual performance in work organization (Motowildlo, 2003). Performance relates only to those behaviors that create a change to organizational aim achievement (Motowildlo, 2003). The performance domain involves behaviors that may have both positive and negative influence on organizational goal attainment (Motowildlo, 2003). For any organization the efficiency of its staff's performance to achieve desirable aims is of utmost important. When it comes to educational and nurture organization, it receives even more attention since it deals with the new generation who served passive roles in teacher centered methods and later become agent and active participants in an era where a classroom is viewed as a small community of different identities and individual differences. In a spectrum of language methodologists, across with attention to learners needs, roles, teachers roles have been perceived a great deal As Mount and Barrick (1998, p.851) proposed "understanding individual differences and their implication for behavior at work is one of our central tenents of our field, and personality characteristics are central to understanding individual differences" (cited in R. Mitchell \& Daniels, 2003, p.239).

A great deal of attention has been devoted to self-regulation in various fields of studies and provoked scholars and psychologists to define different dimensions of this pervasive concept. "Self-regulation (or self-regulated learning) refers to learning that results from student's self-generated thought and behaviors that are systematic oriented toward the attainment of their learning goals" (Schunk \& Zimmerman, 2003,p.59). Self-regulation consists of three subcomponents: self-observation, self-judgment, and self-reaction (Shunk, 1996). Self-observation (italics in original) refers to intentional focus on individual behaviors encompassing determinants and wills, self-judgment (italics in original) includes the consistency between individuals present performance level and their goals and self-reaction (italics in original) refers to humans evaluation of their performance (Schunk, 1996) which is according to Paris and Winograd, (?) generally, people tend to evaluate their own behavior when they feel these behaviors are compatible with "their preferred or desired identity".

"People's beliefs in their efficacy influence the type of anticipatory scenarios they construct and rehearse. Those who have a high sense of efficacy visualize success scenarios that provide positive guides and supports for performance. Those who doubt their efficacy visualize failure scenarios and dwell on the many things that can go wrong" (Bandura, 1993, p.118). When learners set a goal, they find a sense of efficacy which encourages them to devote more time and effort to achieve their goals (Schunk, 1996). In another study teachers' self-regulation was believed to influence teacher's self-efficacy (Ghonsoli \& Ghanizadeh, 2011).

The present study is addressed to investigate the probable relationship between self-regulated strategies and job performance among Iranian EFL teachers. The researchers of the current study are interested in exploring this association based on the logical assumption derived from the theoretical framework of self-regulation theory as well as job performance. The goal setting factor, ( goal setting deals with the idea that most of people function and behavior come from their intentionally chosen goals and intention, Mitchell \& Daniels, 2003), is of utmost importance in self- 
regulation and job performance So, it was hypothesized that the more the teachers employees self-regulated strategies in their classroom, the more it contributes to his/her better professional performance.

\section{THEORETICAL BACKGROUND}

\section{A. Self-regulation}

Based on sociocultural learning theory, cultural factors play a significant role in developing learner's self-regulation and this self-regulation is improved in a meaningful and collaborative environment (Butler, 2002). The interaction between teacher-learner and learner-learner contribute to appropriate application of self-regulated strategies in desired situations (Butler, 2002). Agency is the capability of human beings to make choices in ways that make a difference in their lives (Martin, 2004, cited in Barnard-Brak, Lan, \& Paton, 2010). This agentic aspect offers the human being selfregulated in learning management to perform both autonomously and causally to have an effect on their outcomes and experiences (Barnard-Brak et al, 2010). From this agentic aspect, the self-regulation of learning is taken into consideration as supporting self-deterministic dimension (Barnard-Brak et al, 2010).

Pintrich (2004) stated that most self-regulated learning definitions have four general assumptions in common. The first one is the active constructive assumption (italics in original) which is derived from cognitive aspects. In this perspective learners are expected to construct their own meaning, aims, and techniques from the existing information in their "external" environment and "internal" environment (Pintrich, 2004). A second supposition is the potential for control assumption (italics in original). In this matter students can monitor, check, manage, and regulate particular dimensions of their own cognition, motivation, and behavior and some characteristics of their conditions (Pintrich, 2004). However this assumption does not imply that human can always manage and regulate their cognitive, motivation, and behaviors (Pintrich, 2004). Some checking, managing is possible (Pintrich, 2004).

The goal, criterion or standards assumption (italics in original) constitute the third assumption. Individuals plan a goal to develop their learning and then regulate their cognition, motivation, and behavior for achieving their aims (Pintrich, 2004). The last general assumption is that self-regulatory activities are mediators between personal and contextual characteristics and actual achievement and performance (italics in original). It offers besides cultural, contextual, individual differences, individual's self-regulation of their cognitive, motivation and behavior are significant factors in goal achievement (Pintrich, 2004).

Zimmerman (2008) offered several techniques for evaluating learners' self-regulated learning online such as computer traces, think aloud protocols, structured dairies, direct observation, and macro analytic measure. Zimmerman \& Martinez-pons (1990) found that intelligent students apply more particular self-regulated strategies than their normal peers. These strategies include organizing and transforming, self-consequating, seeking peer help, and reviewing notes (Zimmerman \& Martinez-pons, 1990). These strategies show triadic bidirectional intertwining components of selfregulated learning (Zimmerman \& Martinez-pons, 1990). Organizing and transforming refer to regulating personal processes, self-consequating refers to individual's behavior and reviewing notes and seeking peer help refer to learners' environment (Zimmerman \& Martinez-pons, 1990). Since the teaching profession deals with problem-solving and creativity, it is significant for teachers to get familiar with the notion self-regulation (Paris \& Winograd, ?).

When applying strategies, self-regulated learners evaluate their outcome with regard to the kind of strategy (Butler, 2002). Effective learners self-assess their task achievement according to task criteria rather than their teacher judgment (Butler, 2002). They also translate the offered feedback from their teachers, scores, and peers (Butler, 2002) and use these feedbacks for finding solution for confronted challenges (Randi, 2004). Zimmerman (2002) presents 8 skills which are significant in this process. They include (Van Eekelen, Boshuizen, \& Vermount, 2005):

- Setting particular proximal goals for one self.

- Providing powerful strategies for attaining these goals.

- Monitoring one's performance.

- Reconstructing one's learning environment to be in consistent with ones goal.

- Manipulating one's time effectively.

- Self-assessing one's methods.

- Connecting results to causation.

- Adopting future approaches.

According to developmental theories, the conception of self-regulation in terms of progressive cognitive modifications in students encourages them to take a more dominant role on their thoughts, emotions, and performances (Schunk \& Zimmerman, 1994, cited in Schunk \& Zimmerman, 2003). They assert that "self-regulation does not mean social independence" (Schunk \& Zimmerman, 2003, p. 64); self-regulation progresses primarily from social source and changes to individual sources in a sequence of levels (Schunk \& Zimmerman, 2003). In educational context, beginners quickly acquire learning strategies from teaching social modeling, and task structuring (Schunk \& Zimmerman, 2003). Although the number of social strategies applied by advanced learners is fewer than beginners, it is not implied that social effects disappear with advancing skill acquisition (Schunk \& Zimmerman, 2003). "Self-regulated learning involves goal-directed activities that students instigate, modify, and sustain" (Zimmerman, 1994, 1998, cited in Schunk \& Zimmerman, 2003, p.59). 
Teachers have found the motivation to test their pedagogical practices as a kind of job-embedded staff development (Wilson \& Berne, 1999, cited in Randi, 2004). Little, (2003) proposed that current teacher professional development consider teachers as learners who derive their available information of their teaching experiences to inform their work and professional improvement (Randi, 2004). This type of learning as Reyni, (1996) suggests demands teachers to feel accountability of their own learning. Regarding both teachers and learners, self-regulated strategies are significant (Randi, 2004). ). Randy (2004) introduced 10 characteristics of high quality conditions for teachers in order to improve their self-regulation in educational context. These include:

1. Motivate teachers to create, rather than copy instructional practices.

2. Provide teachers options about instruction.

3. Center on the assessment of instructional practice.

4. Facilitate a pedagogical planning that cycle through planning, enacting, and reflecting on lessons.

5. Offer choices for problem solving.

6. Suggest teachers for learning within the context of teaching.

7. Consider students at the focus of teacher learning.

8. Helping teachers to articulate their knowledge.

9. Scaffolds teachers to higher level of performance, through the strategic use of resources, including mentors.

10. Consist both challenges and support.

She also proposes that "if teaching is to be viewed as a learning opportunity, self-regulated learning strategies seem to be critical skills for teachers to acquire" (2004, p. 1835). "Self-regulated learners are aware when they know a fact or process a skill and when they do not. Self-regulated learners view learning as a systematic and controllable process and they accept greater responsibility for their achievement outcomes (Zimmerman, 1990, p.4)".

Nicole and Macfarlane-Dick, (2006) claimed that formative assessment as a kind of assessment, providing an ongoing feedback of student achievement, led to learner's self-regulation that nourishes the learning process. They indicated seven features of good practice (Nicole and Macfarlane-Dick, 2006):

- Explain what good performance means (goal, criteria, expected standards);

- Assisting the improvement of self-assessment;

- Presenting valuable information to students;

- Motivating teacher and peer discussion;

- Motivating positive motivational beliefs and self-esteem;

- Offering opportunities to remove the distance between current and desired performance;

- Offering information to instructors to form the teaching.

\section{B. Job Performance}

"Job performance is perhaps the most central construct in work psychology" (Viswesvaran, \& Ones, 2000, p.224). The definition of performance as expected behavior value over an appropriate time, is in complete persistent with the supposition proposed by others that a human's performance can shift over time with modifications in motivated criteria and conditional limitations (Motowidlo, 2003). Organ (1988, p.4, cited in Motowildlo, 2003, p.46) defined organizational citizenship behavior as "individual behavior that is discretionary, not directly or explicitly recognized by the formal reward system, and that in the aggregate promotes the effective functioning of the organization".

Sackett and Laczo (2003) offered two different central aspects of job analysis; activity versus attribute. The latter refers to examining worker' performance and behaviors at work labeled 'work-oriented' (italics in original) and the former akin to examining workers personalities such as skill, talent resulting to fulfilling their function on the job- this labeled worker-oriented (italics in original).

Van Scotter and Motowidlo (1996) introduced two dimensions of contextual performance: job dedication and interpersonal facilitation. Job dedication behavior refers to "self-disciplined, motivated acts," and interpersonal facilitation concerns "cooperative, considerate, and helpful acts" (Van Scotter \& Motowidlo,1996 p. 525, cited in Schmitt, Cortina, Ingerick, \& Wiechmann, 2003, p.81).

Considering social exchange theory (SET), the association between work involvement and OCB can be explained (Runhaar, Konermann, \& Sanders, 2013). Runhaar et al., (2013) interpreted this theory in the frame of educational context; teachers represent beneficial behaviors toward their colleagues as well as organization and these behaviors will be reflected by their peers realization and beneficial behaviors. This kind of behavior motivates teachers to become more deeply involved in their job performance Saks, (2006, cited in Runhaar et al., 2013). Runhaar et al, (2013) defined OCBI and OCBO proposed by Williams and Anderson (1991). In this definition OCBI refers to "helping-behavior towards individual colleagues" (p. 100) such as a teacher assists his/her fellow to manage his/her professional difficulties and OCBO refers to "helping-behavior directed towards the organization as a whole" (p. 100)as when a teacher is interested a in carrying out an extra activity. Runhaar et al, (2013) found that there is a correlation between teacher's age and organizational citizenship behavior. The older the teachers are, the more organizational citizenship behavior they possess with the explanation that the more experienced and well aware of teaching skills teachers are, the better their job performance is (Runhaar et al., 2013). 
Campbell (1990) proposed a multifactor model of job performance consisted of eight components (cited in Motowildlo, 2003, p.43):

- Job-specific task proficiency,

- Non-job-specific task proficiency,

- Written and oral communication,

- Demonstrating effort,

- Maintaining personal discipline,

- Facilitating team and peer performance,

- Supervision,

- Management and administration,

Also, Hackman and Oldman, (1976, cited in Hulin \& Judge, 2003, p.262) designed a job characteristics model (JCM) which they suggested (JCM) enriched work with more challenges. It includes five job characteristics (Hackman and Oldman, 1976, cited in Hulin \& Judge, 2003, p.262) :

- Task identity-degree to which one can see ones work from beginning to end.

- Task significance-degree to which ones work is seen as important and significant.

- Skill variety-degree which job allows employees to perform different tasks.

- Autonomy-degree to which employees can regulate their job.

- Feedback-degree to which the work itself offers feedback.

In the present day, the dichotomy between analytical and global styles of learning is a fixed characteristic that has received a great deal of attention (Rafalldi, Iannello, Vittani, \& Antonietti 2012). "Analytical (italics in original) individuals have a focused attention: they have an interest in operations and procedures or the "proper" ways of doing things and prefer step-by-step planning" (Rafalldi et al., 2012, p.2). Global (italics in original) people prefer to scan and form the whole impressions and it makes them integrate their emotions into decision making and logical functions (.Rafalldi et. Al, 2012).

Regarding the above mentioned points, the present study aims to answer the following questions:

1. Is there any significant relationship between teachers' self-regulated strategies in their educational context and their job performance?

2. Among components of self-regulation, which component is the best predictor of teacher's job performance?

\section{Methodology}

\section{A. Participants}

80 Iranian EFL teachers $(\mathrm{N}=80)$ took part in this research. Among these participants, 36 were male and 44 were female. The majority of these participants graduated in different fields of English, 30 had an MA or were students of MA of English teaching, 21 had a BA in English literature, 12 had an MA or were students of MA in English translation. 17 of these participants were from other sciences. All of them were from different language schools in Mashhad, a city in the Northeast of Iran. Their ages varied from 28 to 43 years old. Their teaching experiences varied from 5 years to 21 years.

\section{B. Instrumentation}

\section{Teacher Self-Regulation Scale (TSRS)}

To measure teacher self-regulation, the researchers applied the Teacher Self-Regulation Scale (TSRS), designed by Yesim, Sunger and Uzuntiryaki (2009). This scale is based on the model proposed by Zimmerman's self-regulation (Yesim et al., 2009). It comprised of 40 items using six-point Likert scale ranging from (6) "strongly agree" to (1) "strongly disagree". Scores on this test represent teacher's degree of self-regulation as teacher's own self-regulated strategies which they apply in classrooms (Yesim et al., 2009). This test includes 9 factors which are elaborated on in the table1. In the present study the Cronbach's alpha of this measurement was 0.80 .

TABLE 1.

NINE FACTORS OF TSRS ALONG WITH CORRESPONDING DESCRIPTIONS

\begin{tabular}{|ll|}
\hline Factor & \multicolumn{1}{c}{ Description } \\
\hline $\begin{array}{l}\text { (1) Goal setting } \\
\text { (2) Intrinsic interest }\end{array}$ & Process of establishing objectives to guide actions during instruction \\
(3) Performance goal & Beliefs concerning personal interest in the profession \\
orientation & Goals to do better than others as a teacher and to have other believe in ones competence \\
orientation & Goals to improve competence in teaching And master the teaching \\
(5) Self-instruction & task against self-set standards \\
(6) Emotional control & Process of monitoring one s own performance in teaching and making instructional changes when necessary \\
(7) Self-evaluation & Strategies for controlling and regulating affect, mood, and emotions \\
& Process of evaluating current teaching performance by comparing it \\
(8) Self-reaction & with previously established goal and past performance \\
(9) Help-seeking & Affective responses following a teaching performance \\
\hline
\end{tabular}




\section{Job Performance Scale}

For measuring teacher's job performance, the job performance scale designed by Paterson (1990) was applied. This questionnaire consists of 15 items encompassing four point Likert scale from "always" to "rarely". In this study the Cronbach's alpha for the present questionnaire was 0.84 .

\section{Procedure}

The process of data collection was carried out for twelve weeks. The participants were given the TSRS to fill in for 20 minutes. Then they completed job performance scale for 10 minutes. In order to analyze the data, the researchers applied SPSS version 20. To explore whether there was any correlation between teachers' self-regulation and job performance, Pearson-product moment correlation was employed. At the end, by applying step-wise regression the researchers found out which sub-capabilities of TSRS was a positive predictor of job performance.

\section{FINDINGS AND DiSCUSSION}

In order to determine whether a link exists between teachers' self-regulation and their job performance, a Pearson Product Moment correlation was performed, the result of which revealed a significant positive correlation between the two variables $(r=0.500, P<.01)$.

\begin{tabular}{|c|c|c|c|}
\hline \multicolumn{4}{|c|}{ Correlations } \\
\hline $\begin{array}{l}\text { Job } \\
\text { performance }\end{array}$ & Self-regulation & & \\
\hline $\begin{array}{l}.500^{*} \\
.000\end{array}$ & 1 & $\begin{array}{l}\text { Pearson Correlation } \\
\text { Sig. (2-tailed) }\end{array}$ & $\begin{array}{l}\text { Self- } \\
\text { regulation }\end{array}$ \\
\hline 80 & 80 & $\mathrm{~N}$ & \\
\hline 1 & $\begin{array}{l}.500^{* *} \\
.000\end{array}$ & Pearson Correlation & $\begin{array}{l}\text { Job } \\
\text { performanc }\end{array}$ \\
\hline 80 & 80 & $\mathrm{~N}$ & $\mathrm{e}$ \\
\hline
\end{tabular}

To further analyze the data, the researchers conducted the regression analysis with a Stepwise method. The results revealed that among the subcomponents of self-regulation, mastery orientation goal is the best predictor of teacher total job performance (adjusted $\mathrm{R}^{2}=.455, \mathrm{p}<0.5$ ) indicating that teachers who scored high on mastery orientation goal performed better at work.

STEPWISE REgRESSION ANALYSIS PREDICTING JOB PERFORMANCE

STEPWISE REGRESSION ANALYSIS PREDICTING JOB PERFORMANCE
\begin{tabular}{|l|l|l|l|l|l|l|}
\hline Beta & $\mathrm{F}$ & Std. Error of the Estimate & Adjusted R Square & R Square & R & Model \\
\hline .680 & 67.026 & 4.53542 & .455 & .462 & $.680^{\mathrm{a}}$ & Mastery-orientation goal \\
\hline
\end{tabular}

\section{CONCLUSION AND SUGGESTION}

Consistent with the hypothesized relationship between teachers' self-regulation and their job-performance, the findings of the present research demonstrate a significant correlation between teachers' self-regulation and job performance. This is compatible with theoretical and empirical research that center on the role of individual differences in professional performance. Vancouver (2000) stated that, in work context, self-regulation involves the creation of goals, the creation of a tool to achieve goals, or shifting ways for evaluating present levels (Randi, 2004). This perspective characterizes self-regulation in terms of attaining particular tasks. In organizations-centered on productivity, work is respected over learning and learning is improved for work's sake (Randi, 2004). Consistent with changes in learner's roles from passive learners to active participants (Randi \& Corno, 2000, cited in Randi, 2004), teachers professional roles have changed from workers to learners which demands teachers to improve volitional learning strategies as well as volitional work styles (Randi, 2004). In a similar line, it is revealed that there is a high linkage between EFL teachers pedagogical success and their application of self-regulated strategies at their teaching environment (Monshi Toussi \& Boori \& Ghanizadeh, 2012).

In the present study all participants were teaching in language institutes where it was supposed that the frames of teaching manuals represent similar instructions regarding course books which (e.g. Interchange, Top Noch,) are thought. These books focus on learners' need, autonomy, responsibility as well as a focus on teachers' roles as facilitators. Teachers are required to follow the principles. Both teachers and learners are encouraged to create a meaningful context and directly or indirectly highlight the implementation of self-regulated strategies such as taking advantage of students' feedback and control their emotions (Randi, 2004). These conditions enrich the quality of learning environment in which learners learn to have an aim to progress, to feel accountable for their process (Schunk, 1996), and it is sensible to assume this influences teachers' job performance.

Holland (1973), postulated that professional and job satisfaction, morale, productivity, and attainment rely on the correlation between humans personality and their job context (Hough\& Furnham, 2003). Teachers with a high level of efficacy are aware of applying the appropriate strategies at the apt situations (Randi, 2004; y) which leads to learners' 
autonomy particularly in these days of post method era. According to Kumaravdivelu (2006) "the post method learner, is an autonomous learner. Because language learning is largely an autonomous activity, promoting learner autonomy is vitally important". Self-regulated learners feel autonomous and they become active even when encountering problems and laden fruitless conditions and for creating this condition, teachers play a critical role especially when both teachers and learners are viewed on the same page (Newman 2002). Interpreted in teacher education, teachers tend to enrich the quality of both teaching as well as learning by employing different patterns of self-regulated strategies and shift these techniques whenever modifications are necessary (Randi, 2004).

With respect to the second question of the present study, the results of the finding indicated that mastery orientation goal is the best predictor of teachers' job performance. This result is consistent with Yesim, Sunger and Uzuntiryaki (2009) indicated that teachers with mastery orientation goals take more consideration towards improving new abilities, developing competence, and fulfilling task rather than personal achievements. They respect the quality of teaching so they devote extra effort and time to cope with existing challenges in the educational context (Yesim et al., 2009). In learning process mastery orientation goals due to their quality of challenge are preferred to performance orientation goals Paris \& Winograd, (?).

The present study has some limitation. The role of English teaching background, degree, gender have not be concerned so it was suggested a further research including the above factors. Regarding the dramatic changes in teachers' roles from transferring of information and knowledge to supporting self-regulated students learning, it seems highly critical that teachers be cognizant of essential skills (Van Eekelen et al, 2005). Researchers emphasize that it is applicable to teach self-regulatory strategies which contribute to learners' achievement and enhancing their self-efficacy (Schunk, 1996).

\section{REFERENCES}

[1] Bandura, A. (1993). Perceived self-efficacy in Cognitive Development and Functioning. Educational Psychology, 28(2), 117148. http://www.centerforefficacyandresiliency.org/assets/docs/Perceived\%20Self-Efficacy\%20in $\% 20$ Cognitive $\% 20$ Development\%20and\%20Functioning.pdf (accessed 20/12/2012).

[2] Barnard, L., Lan, W. Y., \& Paton, V. O. (2010). Profiles in Self-Regulated Learning in the Online Learning Environment. International Review of Research in Open and Distance Learning. 11 (1).

[3] http://www.irrodl.org/index.php/irrodl/article/view/769/1480. (accessed 13/4/2013).

[4] Butler, D. L. (2002). Individualizing instruction in self-regulated learning, Theory Into Practice. 41(2), 81-92. http://courses.csusm.edu/lbst361bby/ 1a_articles/ EDUCATION/SelfRegLEARNING/02_LSonline_SRL.pdf. (accessed 12/3/2013). DOI: 10.1207/s15430421tip4102_4.

[5] Capa, Y., Sunger, S., Uzeuntiryaki, E. (2009). Teacher self-regulation: examining a multidimensional construct, Educational Psychology, 29(3), 345-356. DOI: 10.1080/01443410902927825.

[6] Ghonsooli, B., \& Ghanizadeh, A. (2011). Self-efficacy and self-regulation and their relationship among Iranian EFL. Language Learning Journal. 1-17. http://profdoc.um.ac.ir/articles/a/1024259.pdf. (accessed 21/11/2012). DOI:10.1080/09571736.2011.625096.

[7] Hulin, C. L., \& Judge, T. A. (2003). Job Attitudes. In: Borman, W. C., \& Ilgen, D. R, \& Klimoski, R. J. (Eds) Handbook of Psychology (pp. 255-276). Hoboken, New Jersy: John Wiley \& Sons. Inc. https://is.muni.cz/el/1441/podzim2012/SZk1025a/um/Handbook_Of_Psychology__Personality_And_Social_Psychology__Malestrom_.pdf. (accessed 13/4/2013).

[8] Mitchell, T. R., \& Danials, D. (2003) Motivation. In: Borman, W. C., \& Ilgen, D. R, \& Klimoski, R. J. (Eds) Handbook of Psychology (pp. 225-254). Hoboken, New Jersy: John Wiley \& Sons. Inc. https://is.muni.cz/el/1441/podzim2012/SZk1025a/um/Handbook_Of_Psychology__Personality_And_Social_Psychology__Malestrom_.pdf . (accessed 13/4/2013).

[9] Monshi Toussi, M. T., \& Boori, A. K., \& Ghanizadeh, A. (2011). The Role of EFL Teachers Self-regulation in Effective Teaching. World Journal of Education. 1(2), 39-48. http://www.sciedu.ca/journal/index.php/wje/article/download/455/223. (accessed 17/9/2012). doi:10.5430/wje.v1n2p39.

[10] Motowildlo, S. J. (2003) Job Performance. In: Borman, W. C., \& Ilgen, D. R, \& Klimoski, R. J.(Eds) Handbook of Psychology (pp. 39-54). Hoboken, New Jersy: John Wiley \& Sons. Inc. https://is.muni.cz/el/1441/podzim2012/SZk1025a/um/Handbook_Of_Psychology__Personality_And_Social_Psychology__Malestrom_.pdf. (accessed 13/4/2013).

[11] Newman, R. S. (2002). How Self-Regulated Learners Cope with Academic Difficulty: The Role of Adoptive Help Seeking. Theory into Practice, 41(2), 132-138. http://www.drrsnewman.com/pdf/Coping_with_Academic_Difficulty-How_to_Encourage_Help_Seeking.Newman.pdf. (accessed 13/4/2013).

[12] Nicol, D. J., \& Macfarlane-Dick, D. (2006). Formative assessment and self-regulated learning: A model and seven principles of good feedback practice. Studies in Higher Education, $31(2), \quad 199-218$. http://www.reap.ac.uk/reap/public/papers//DN_SHE_Final.pdf. (accessed 13/4/2013).

[13] Paris, S. G., \& Winograd, P. W. (?). The Role of Self-regulation Learning in Contextual Teaching: Principles and Practices for Teacher Preparation. A Commissioned Paper for the U.S. Department of Education Project Preparing Teachers Use Contextual Teaching and Learning Strategies To Improve Success In and Beyond School. Dr. Kenneth R, Howey, Project Director. http://www.ciera.org/library/archive/2001-04/0104parwin.htm. (accessed 13/4/2013).

[14] Pintrich, P.R., \& De Groot E. (1990). Motivational and self-regulated learning components of classroom academic performance. Journal of Educational Psychology, 82(1), 33-50. http://www.reap.ac.uk/public/Papers/DN_SHE_Final.pdf. (accessed 21/11/2012). 
[15] Pintrich, P. R. (2004). A Conceptual Framework for Assessing Motivation and Self-Regulated Learning. Educational Psychology Review, 16(4), 385-407. http://deepblue.lib.umich.edu/bitstream/handle/2027.42/44454/10648_2004_Article_NY00000604.pdf?sequence=1. (accessed 21/11/2012)

[16] Raffaldi, S., \& Iannello, P., \& Vittani, L., \& Antonietti, A. (2012). Decision-Making Styles in the Workplace: Relationships Between Self-Report Questionnaires and a Contextualized Measure of the Analytical-Systematic Versus Global-Intuitive Approach. $\quad S A G E \quad$ Open, $1-11$. DOI: $\quad 10.1177 / 2158244012448082$. http://sgo.sagepub.com/content/2/2/2158244012448082.full.pdf. (accessed 13/4/2013).

[17] Randi, J. (2004). Teachers as self-regulated learners, Teachers College Record, 106, 1825-1853. http://portfolio.project.tcnj.edu/summer2008/Kinney/Articles/gordonk-Teachers_as_Self_Regulated_Learners-5254108108.pdf. (accessed 18/3/2013).

[18] Runhaar, P., \& Konermann, J., \& Sanders, K. (2013). Teachers' organizational citizenship behaviour: Considering the roles of their work engagement, autonomy and leaderemember exchange. Teaching and Teacher Education 30, 99-108. http://dx.doi.org/10.1016/j.tate.2012.10.008.

[19] Sackett, P. R., \& Laczo, R. M. (2003). Job and Work Analysis. In: Borman, W. C., \& Ilgen, D. R, \& Klimoski, R. J. (Eds) Handbook of Psychology (pp. 21-38). Hoboken, New Jersy: John Wiley \& Sons. Inc. https://is.muni.cz/el/1441/podzim2012/SZk1025a/um/Handbook_Of_Psychology__Personality_And_Social_Psychology__Malestrom_.pdf. (accessed 13/4/2013).

[20] Schmitt, N., \& Cortina, J. M., \& Ingerick, M. J., \& Wiechmann, D. (2003). Personal Selection and Employee Performance. In: Borman, W. C., \& Ilgen, D. R, \& Klimoski, R. J. (Eds) Handbook of Psychology (pp. 77-106). Hoboken, New Jersy: John Wiley \& Sons. Inc. https://is.muni.cz/el/1441/podzim2012/SZk1025a/um/Handbook_Of_Psychology__Personality_And_Social_Psychology__Malestrom_.pdf. (accessed 13/4/2013).

[21] Schunk, D. H. (1996). Goal and self-evaluation influences during children s cognitive skill learning. American Educational Research Journal, 33, 359-382. http://libres.uncg.edu/ir/uncg/f/D_Schunk_Goal_1996.pdf. (accessed 13/4/2013).

[22] Schunk, D. H., \& Zimmerman, B. J. (2003). Self-regulation and Learning. In: Reynolds, W. M., \& Miller, I. B. (Eds) Handbook of Psychology pp.59-78. New Jersey, NJ: John Wiley \& Sons. Inc. http://www.researchgate.net/publication/228003084_Relationships_Between_Teachers_and_Children/file/72e7e51507ad366d2 7.pdf. (accessed 13/4/2013).

[23] Van Eekelen, I. M., Boshuizen, H.P.A., Vermunt, J. D. (2005) Self-regulation in higher education teacher learning. Higher Education, 50, 447-471. http://igitur-archive.library.uu.nl/ivlos/2007-0106200146/Article\%20Van\%20Eekelen\%20et\%20al\%202005\%20High\%20Educ.pdf. (accessed 18/3/2013). DOI 10.1007/s10734-004-6362-0.

[24] Viswesvaran, C., \& Ones, D. S. (2000). Perspectives of Models of Job Performance. International Journal of Selection and Assessment, $\quad 8(4) \quad 216-226$ http://myweb.usf.edu/ jdorio/Performance\%20App/Viswesvaran,\%20C.,\%20\%26\%20Ones,\%20D.\%20S.\%20(2000)..pdf (accessed 13/4/2013).

[25] Zimmerman, B. J. (1990). Self-regulated Learning and Academic Achievement: An Overview. Educational Psychologist, 25(1), 3-17. p://www.unco.edu/cebs/psychology/kevinpugh/motivation_project/resources/zimmerman90.pdf. (accessed 13/4/2013).

[26] Zimmerman, B. J., \& Martinez-Pons, M. (1990). Student Differences in Self-Regulated Learning: Relating Grade, Sex, and Giftedness to Self-Efficacy and Strategy Use. Journal of Educational Psychology, 82(1), 51-59. http://www.researchgate.net/publication/232583872_Student_differences_in_self-

regulated_learning_Relating_grade_sex_and_giftedness_to_self-efficacy_and_strategy_use/file/79e41512c2ef708a73.pdf. (accessed 19/8/2012).

[27] Zimmerman, B. J. (2008). Investigating Self-regulation and Motivation: Historical Background, Methodological Development, and Future Prospects. American Educational Research Journal, 45(1), $166 \quad-183$. http://campestre.phipages.com/storage/.instance_12129/Self_Regulation_and_Motivation.pdf(accessed 13/4/2013). DOI: $10.3102 / 0002831207312909$.

Atiyeh Kamyabi Gol was born in 1983. She is an assistant professor at the Faculty of Letters and Humanities, Ferdowsi University of Mashhad. She received her PhD degree in Applied Linguistics from University of Malaya, Malaysia in 2012. She received her M.A. degree in English language teaching from Ferdowsi University of Mashhad, Mashhad, Iran in 2009, and she also got the B.A. degree in English language and literature from Ferdowsi University of Mashhad, Mashhad, Iran in 2006. Her areas of research include Second language writing, Applied linguistics, Cultural aspects of EFL, Perceived culture, Anxiety in EFL learning, Self disclosure in EFL teaching and learning. She has published in the areas of Cultural Attachment and Accent Mimicry and also Home Culture Attachment.

Nahid Royaei is a TEFL student of M.A. at Imam Reza International University. Her major interests are psychology, sociology, and teacher education. 